\title{
The Importance of Providing Incentives and Motivation in Improving Employee Performance
}

\author{
Sihabudin \\ Universitas Buana Perjuangan Karawang, Indonesia \\ Email: sihabudin@ubpkarawang.ac.id
}

\begin{abstract}
This study aims to examine the effect of incentives and motivation on employee performance at PT. Hurip Utama Cikampek. This research was conducted using descriptive and verification methods, namely collecting, presenting, analyzing, and testing hypotheses, and making conclusions. Samples were collected using the Incidental Random Sampling method with a total sample of 128 respondents from a population of 281 people. Data analysis techniques used are scale range analysis techniques and SPSS version 22 path analysis. The results of this study prove that there is an influence between incentives and motivation on employee performance at PT. Hurip Utama Cikampek both partially and simultaneously.
\end{abstract}

Keywords: HRM, Incentives, Motivation, Performance.

\section{A. INTRODUCTION}

The growing business world in Indonesia requires companies to maintain and further improve the quality of work and the number of services to the company's stakeholders. Human resources need to be developed and considered so that the quality of human resources can be improved so that it has an impact on increasing company performance.

To be able to maintain good performance, management should pay attention to several factors that can affect performance, one of which is incentives. Providing incentives is a reward given to an employee who has done a job outside his main task or exceeds the target of the job. Incentives are very important for employees to stimulate someone to do work beyond what is desired by the company.

In addition to incentives, the factors that affect performance are motivation. According to Mathis \& Jackson (2001), the factors that influence the performance of the individual workforce are their ability, motivation. The motivation that will affect the performance of the workforce is potential, where a person has to achieve optimal results. Based on the description above, the purpose of this study is to examine the effect of incentives and motivation on employee performance at PT. Hurip Utama Cikampek. 


\section{B. LITERATURE REVIEW}

\section{Incentive}

According to Mangkunegara, incentives are rewards on the basis of high work performance which is a sense of recognition from the organization of employee work performance and contribution to the organization (Yani, 2012).

According to Martoyo, an incentive is an additional salary (bonus) due to an excess of achievement that differentiates it from the others, which is intended to increase employee productivity and maintain employees who excel to remain in the organization (Yani, 2012).

According to Panggabean, incentives are compensation that links salary to productivity, incentives are rewards in the form of money based on those who can work through predetermined standards (Yani, 2012).

\section{Motivation}

According to Robbins \& Counter, motivation is the willingness to carry out high efforts to achieve organizational goals which are conditioned by the ability of efforts to meet the needs of certain individuals (Suwanto \& Priansa, 2011).

According to Hasibuan, motivation is the giving of a driving force that creates the excitement of one's work so that they will cooperate, work effectively and be integrated with all their efforts to achieve satisfaction (Sutrisno, 2009).

According to Robbins, motivation is a willingness to try as optimal as possible in achieving organizational goals that are influenced by the ability of businesses to satisfy some individual needs (Sutrisno, 2009).

\section{Employee Performance}

According to Mahsum, performance is a picture of the level of achievement of the implementation of an activity/program/policy in realizing the goals, objectives, mission, and vision of the organization (Sembiring, 2012).

According to Mangkunegara (2011), performance is the result of the quality and quantity of work achieved by an employee in carrying out their duties in accordance with the responsibilities given to him.

According to Yunarsih \& Suwanto (2008), performance is a real achievement displayed by a person after carrying out their duties and roles in the organization.

\section{METHOD}

This research was conducted at PT. Hurip Utama Cikampek by using descriptive and verification methods, namely collecting, presenting, analyzing, and testing hypotheses, and making conclusions. Based on the level of expansion of this study, including associative research. Associative Analysis is research that aims to examine the relationship between two or more variables. Samples were collected using the Incidental Random Sampling method with a total sample of 128 respondents from a population of 281 people. Data analysis techniques used in this study are scale range analysis techniques and path analysis using SPSS version 22. 


\section{RESULT AND DISCUSSION}

\section{Recapitulation of Incentive Variable Indicators $\left(\mathbf{X}_{\mathbf{1}}\right)$}

Recapitulation of the results of respondents' answers to the incentive variable indicator $\left(\mathrm{X}_{1}\right)$ can be described in table 1 as follows:

Table 1 Recapitulation of Incentive Variable Indicators $\left(X_{1}\right)$

\begin{tabular}{|c|l|c|c|}
\hline No & \multicolumn{1}{|c|}{ Indicator } & Total Score & Information \\
\hline 1 & Bonus & 437 & Agree \\
\hline 2 & Commission & 396 & Quite Agree \\
\hline 3 & Profit-sharing & 454 & Agree \\
\hline 4 & Deferred compensation & 491 & Agree \\
\hline 5 & Old age help & 480 & Agree \\
\hline 6 & Problem guarantee & 450 & Agree \\
\hline 7 & Awarding an award certificate & 463 & Agree \\
\hline 8 & Granting promotions & 476 & Agree \\
\hline 9 & Giving oral or written praise & 488 & Agree \\
\hline \multicolumn{2}{r|}{ Total Score } & $\mathbf{4 . 1 3 5}$ & Agree \\
\hline \multicolumn{2}{r|}{ Average Score } & \\
\hline
\end{tabular}

Source: Data Processing Results, 2018

The incentives for PT Hurip Utama Cikampek are good, this is evidenced by the respondents being in the criteria of agreeing with an average score of 459.4. But there are still indicators with the smallest score, which are commission indicators with a score of 396. And 8 other indicators with agreed criteria are bonus indicators, profit sharing, deferred compensation, old-age assistance, social security, awarding certificates, granting promotion, giving verbal praise or writing.

\section{Recapitulation of Motivational Variable Indicators $\left(X_{2}\right)$}

The recapitulation of the results of the respondents' answers to the indicator variable motivation $\left(X_{2}\right)$ is described in table 2 as follows:

Table 2 Recapitulation of Motivational Variable Indicators $\left(X_{2}\right)$

\begin{tabular}{|c|l|c|c|}
\hline No & \multicolumn{1}{|c|}{ Indicator } & Total Score & Information \\
\hline 1 & Meeting basic needs & 509 & Agree \\
\hline 2 & Work uniform & 499 & Agree \\
\hline 3 & Work safety protection & 497 & Agree \\
\hline 4 & Safety and comfort at work & 351 & Quite Agree \\
\hline 5 & Continuation of work & 482 & Agree \\
\hline 6 & Association with coworkers & 449 & Agree \\
\hline 7 & Co-workers' assistance & 363 & Quite Agree \\
\hline 8 & Family support & 472 & Agree \\
\hline 9 & appreciation & 465 & Agree \\
\hline 10 & Part of the company & 471 & Agree \\
\hline 11 & Useful for the company & 454 & Agree \\
\hline 12 & Development of training and education & 353 & Quite Agree \\
\hline
\end{tabular}




\begin{tabular}{|c|c|c|}
\hline Total Score & 5365 & \multirow{2}{*}{ Agree } \\
\cline { 1 - 2 } Average Score & 447,1 & \\
\hline
\end{tabular}

Source: Data Processing Results, 2018

Motivation at PT Hurip Utama Cikampek is good, this is evidenced by the respondents being in the criteria of agreeing with an average score of 447.1. But there are still indicators with the smallest score, which are safety and comfort indicators in working with a score of 351, assistance of colleagues with a score of 363, development of training and education with a score of 353. And 9 other indicators with agreed criteria are indicators of meeting basic needs, work uniforms, protection work safety, continuity of work, association with colleagues, family support, appreciation, part of the company, benefit the company.

\section{Recapitulation of Employee Performance Variable Indicators (Y)}

The recapitulation of the results of respondents' answers to the employee performance indicator variable $(\mathrm{Y})$ can be described in table 3 as follows:

Table 3 Recapitulation of Performance Variable Indicators (Y)

\begin{tabular}{|c|c|c|c|}
\hline No & Indicator & $\begin{array}{l}\text { Total } \\
\text { Score }\end{array}$ & Information \\
\hline 1 & Carry out the tasks well & 509 & Agree \\
\hline 2 & Execution of tasks on time & 499 & Agree \\
\hline 3 & Leadership satisfaction & 497 & Agree \\
\hline 4 & satisfaction of coworkers & 475 & Agree \\
\hline 5 & Knowledge of tasks and procedures & 482 & Agree \\
\hline 6 & Provide ideas / suggestions & 449 & Agree \\
\hline 7 & Collaboration with colleagues & 363 & Quite Agree \\
\hline 8 & Cooperation with leaders & 472 & Agree \\
\hline 9 & Leader's trust & 465 & Agree \\
\hline 10 & Recognize and understand problems & 471 & Agree \\
\hline 11 & Relationship with leadership & 454 & Agree \\
\hline 12 & Relationships with coworkers & 353 & Quite Agree \\
\hline & $\begin{array}{c}\text { Total Score } \\
\end{array}$ & 5489 & \multirow{2}{*}{ Agree } \\
\hline & Average Score & 457,4 & \\
\hline
\end{tabular}

Source: Data Processing Results, 2018

The performance of employees at PT Hurip Utama Cikampek is good, this is evidenced by the respondents being in the criteria of agreeing with an average score of 457.4. But there are still indicators with the smallest score, namely indicators of collaboration with coworkers with a score of 363, relationship with coworkers with a score of 353. And other indicators with agreed criteria are indicators of good task implementation, timely execution of tasks, leadership satisfaction, satisfaction of colleagues, knowledge of tasks and procedures, provide ideas or suggestions, collaboration with leaders, trust leaders, recognize and understand problems, relationships with leaders. 


\section{Path Analysis}

The following presents the results of the path analysis between the incentive variables (X1) and motivation (X2) on employee performance (Y) in table 4 as follows:

Tabel 4 Path Analysis

Coefficients $^{a}$

\begin{tabular}{|cc|c|c|c|c|c|}
\hline & \multirow{2}{*}{ Model } & \multicolumn{2}{|c|}{$\begin{array}{c}\text { Unstandardized } \\
\text { Coefficients }\end{array}$} & $\begin{array}{c}\text { Standardized } \\
\text { Coefficients }\end{array}$ & & \\
\cline { 2 - 5 } & $\mathrm{B}$ & Std. Error & Beta & $\mathrm{t}$ & Sig. \\
\hline \multirow{2}{*}{1} & (Constant) & 10.711 & 2.042 & & 5.247 & .000 \\
& Incentive & .386 & .129 & .329 & 2.985 & .003 \\
& Motivation & .396 & .093 & .470 & 4.260 & .000 \\
\hline
\end{tabular}

a. Dependent Variable: Performance

Source: Data Processing Results, 2018

The table above shows the value of the path coefficient between the incentive variables $\left(\mathrm{X}_{1}\right)$ and motivation $\left(\mathrm{X}_{2}\right)$ on employee performance $(\mathrm{Y})$. The path coefficient values for the incentive variable $\left(\mathrm{X}_{1}\right)$ on employee performance $(Y)$ are 0.329 . This shows that the variable of direct motivation $\left(X_{1}\right)$ to the employee performance variable $(\mathrm{Y})$ is 0.329 , so the equation $\mathrm{Y}=0.329 \mathrm{X} 1$ is obtained. While the path coefficient for the motivation variable $\left(\mathrm{X}_{2}\right)$ to the employee performance variable $(\mathrm{Y})$ is 0.470 . This shows that the variable of direct motivation $\left(\mathrm{X}_{2}\right)$ on employee performance variables $(\mathrm{Y})$ is 0.470 , so that the coefficient $\mathrm{Y}=0.470 \mathrm{X}_{2}$ is obtained.

\section{Analysis of the Coefficient of Determination}

The total effect of the incentive variables $\left(X_{1}\right)$ and motivation $\left(X_{2}\right)$ on employee performance $(\mathrm{Y})$ is expressed by the magnitude of the coefficient of determination $\left(\mathrm{R}^{2}\right)$. The amount of $\mathrm{R}^{2}$ can be seen in table 5 below:

Table 5 Coefficient of Determination $\left(\mathbf{R}^{2}\right)$

\begin{tabular}{|l|r|r|r|c|}
\hline \multicolumn{7}{|c|}{ Model Summary } \\
\hline Model & $\mathrm{R}$ & R Square & $\begin{array}{c}\text { Adjusted R } \\
\text { Square }\end{array}$ & $\begin{array}{c}\text { Std. Error of the } \\
\text { Estimate }\end{array}$ \\
\hline 1 & $.771^{\mathrm{a}}$ & .595 & .588 & 3.91328 \\
\hline
\end{tabular}

a. Predictors: (Constant), Motivation, Incentive

Source: Data Processing Results, 2018

Based on table 5 above shows that the coefficient of determination $\left(R_{2}\right)$ of 0.595 or $59.5 \%$, the employee performance variable (Y) can be explained by the incentive variables $(\mathrm{X} 1)$ and motivation $\left(\mathrm{X}_{2}\right)$ or can be interpreted as incentives $\left(\mathrm{X}_{1}\right)$ 
and motivation ( X2) has a contribution to employee performance (Y) of $59.5 \%$, while the remaining $40.5 \%$ is contributed by other variables $(\varepsilon)$ which are not examined.

\section{E. CONCLUSION}

The results of this study prove that there is an influence between incentives and motivation on employee performance at PT. Hurip Utama Cikampek both partially and simultaneously. Partially, the effect of incentives on employee performance is 0.108 , while the effect of motivation on employee performance is 0.221 . Because 0.108 is greater than 0.221 , it is stated that the motivational variable contributes more to employee performance than the incentive variable. Simultaneously, the effect of incentives and motivation on employee performance was $59.5 \%$, while the remaining $40.5 \%$ was contributed by other variables not examined in this study.

\section{REFERENCES}

1. Arilianti, S., Rahman, T., \& Sumarni, I. (2019). Pengaruh Insentif Terhadap Kinerja Karyawan Melalui Motivasi pada CV. Yazid Bersaudara Cabang Tanjung Kabupaten Tabalong. JAPB, 2(1), 281-291.

2. Asim, M. (2013). Impact of Motivation on Employee Performance with effect of training: Specific to Education Sector of Pakistan. International Journal of Scientific and Research Publications, 3(9), 1-9.

3. Bangun, W. (2012). Manajemen Sumber Daya Manusia. Jakarta: Erlangga.

4. Bungin, B. (2005). Metode Penelitian Kuantitatif. Jakarta: Kencana.

5. Gomes, F. C. (2003). Manajemen Sumber Daya Manusia. Yogyakarta: Andi Offset.

6. Handoko, T. H. (2006). Manajemen Personalia dan Sumber Daya Manusia. Yogyakarta: BPFE.

7. Hasibuan, M. S. P. (2011). Manajemen dasar Pengertian dan Masalah. Jakarta: Bumi Aksara.

8. Hatip, A. (2012). Pengaruh Kompenasasi dan Motivasi Kerja Terhadap Kinerja Karyawan pada PT. Pupuk Kujang Cikampek. (Thesis, Faculty of Economics and Business, Singaperbangsa University, Karawang).

9. Koswara, Y. (2011). Pengaruh Pemberian Insentif Terhadap Kinerja Pegawai Pada Rumah Sakit Cito Karawang. (Thesis, Faculty of Economics and Business, Singaperbangsa University, Karawang).

10. Lin, H. F. (2007). Effects of extrinsic and intrinsic motivation on employee knowledge sharing intentions. Journal of information science, 33(2), 135-149.

11. Maduka, C. E., \& Okafor, O. (2014). Effect of motivation on employee productivity: A study of manufacturing companies in Nnewi. International Journal of Managerial Studies and Research, 2(7), 137-147.

12. Mangkunegara, A. A. A. P. (2011). Manajemen Sumber Daya Manusia Perusahaan. Bandung: Remaja Rosdakarya. 
13. Omollo, P. A., \& Oloko, M. A. (2015). Effect of motivation on employee performance of commercial banks in Kenya: A case study of Kenya Commercial Bank in Migori County. International journal of human resource studies, 5(2), 87-103.

14. Prabowo, D. A. (2009). Analisis Hubungan Tunjangan Insentif Kinerja Dengan Motivasi Kerja Karyawan Pada PT Pupuk Kujang Cikampek. (Thesis, Faculty of Economics and Business, Singaperbangsa University, Karawang).

15. Rivai, V. (2008). Manajemen Sumber Daya Manusia untuk Perusahaan. Jakarta: Rineka Cipta.

16. Rumansyah, H. B. (2012). Pengaruh Motivasi Terhadap Kinerja Karyawan Pada Outlet PT Sinarmas Multifinance di Telagasari Kabupaten Karawang. (Thesis, Faculty of Economics and Business, Singaperbangsa University, Karawang).

17. Sugiyono. (2013). Metode Penelitian Kuantitatif Kualitatif dan RED. Bandung: Alfabeta.

18. Sutrisno, E. (2009). Manajemen Sumber Daya Manusia. Jakarta: Kencana.

19. Siagian, S. P. (2014). Manajemen Sumber Daya Manusia. Jakarta: Bumi Aksara.

20. Suwanto \& Priansa, D. J. (2011). Manajemen SDM dalam Organisasi Publik dan Bisnis. Bandung: Alfabeta.

21. Sedarmayanti. (2009). Sumber Daya Manusia dan Produktivitas Kerja. Bandung: Mandar Maju.

22. Sembiring, M. (2012). Budaya dan Kinerja Organisasi. Bandung: Fokusmedia.

23. Sutrisna, R. (2012). Pengaruh Motivasi Kerja dan Kompensasi Terhadap Kinerja Petugas Pengelola Kebersihan Pada Seksi Kebersihan Dinas Cipta Karya Kabupaten Karawang. (Thesis, Faculty of Economics and Business, Singaperbangsa University, Karawang).

24. Yani, A. (2012). Manajemen Sumber Daya Manusia. Jakarta: Mitra Wacana Media.

25. Yuniasih, T. (2009). Manajemen Sumber Daya Manusia. Bandung: Alfabeta. 